\title{
Article
}

\section{Welfare spending and quality of growth in developing countries: A note on evidence from Hopefuls, Contenders and Best Performers}

Asongu, Simplice A. and Nwachukwu, Jacinta Chikaodi

Available at http://clok.uclan.ac.uk/24917/

Asongu, Simplice A. and Nwachukwu, Jacinta Chikaodi ORCID: 0000-00032987-9242 (2016) Welfare spending and quality of growth in developing countries: A note on evidence from Hopefuls, Contenders and Best

Performers. The Social Science Journal, 53 (4). pp. 495-500. ISSN 0362-3319

It is advisable to refer to the publisher's version if you intend to cite from the work. http://dx.doi.org/10.1016/j.soscij.2016.08.006

For more information about UCLan's research in this area go to http://www.uclan.ac.uk/researchgroups/ and search for <name of research Group>.

For information about Research generally at UCLan please go to http://www.uclan.ac.uk/research/

All outputs in CLoK are protected by Intellectual Property Rights law, including Copyright law. Copyright, IPR and Moral Rights for the works on this site are retained by the individual authors and/or other copyright owners. Terms and conditions for use of this material are defined in the policies page. 


\title{
$\underline{\text { A G D I Working Paper }}$
}

\section{$\mathrm{WP} / 16 / 028$}

\section{Welfare Spending and Quality of Growth in Developing Countries: A Note on Evidence from Hopefuls, Contenders and Best Performers}

Forthcoming: The Social Science Journal

\author{
Simplice A. Asongu \\ African Governance and Development Institute, \\ P.O. Box 8413 Yaoundé, Cameroon. \\ E-mail: asongusimplice@yahoo.com lasongus@afridev.org \\ Jacinta C. Nwachukwu \\ School of Economics, Finance and Accounting, \\ Faculty of Business and Law, \\ Coventry University \\ Priory Street, Coventry, CV1 5FB, UK \\ Email: jacinta.nwachukwu@ coventry.ac.uk
}




\title{
AGDI Working Paper
}

\author{
Research Department
}

\section{Welfare Spending and Quality of Growth in Developing Countries: A Note on Evidence from Hopefuls, Contenders and Best Performers}

\section{Simplice A. Asongu \& Jacinta C. Nwachukwu}

June 2016

\begin{abstract}
The transition from the Millennium Development Goals (MDGs) to Sustainable Development Goals (SDGs) has shifted the policy debate from growth to 'quality of growth' (QG). We explore a new dataset on QG by the IMF and classify 93 developing countries for the period 1990-2011 in terms of Hopefuls, Contenders and Best Performers. The aims are as follows: (i) to depict the contradiction between high-growth and poor social welfare and (ii) to assess the influence of education and health spending on the QG. We use quantile regressions to articulate least and best QG performers. Two key findings emerge. First, 31 of the 33 countries in the Hopefuls category are in SSA. Second, the effect of health is decreasingly positive from Hopefuls to Best Performers, while the impact of education is increasingly positive. As a main policy implication, it would benefit countries in SSA to invest more in health relative to education now, but decrease such health expenditure and increase education spending as the economies in the sub-region make the transition from Hopeful to Contenders and finally to Best Performers in terms of 'quality of growth'.
\end{abstract}

JEL Classification: O40; O57; I10; I20; I32

Keywords: Quality of growth; Development; Education; Health 


\section{Introduction}

'Output may be growing, and yet the mass of the people may be becoming poorer' (Lewis, 1955). In the transition from Millennium Development Goals (MDGs) to Sustainable Development Goals (SDGs), the policy debate has been shifting from growth to growth quality. The relevance of the underlying policy debate has been fuelled by the April $15^{\text {th }} 2015$ publication of World Development Indicators which revealed that poverty has been decreasing in all regions of the world, with the exception of Sub-Saharan Africa (Asongu \& Kodila-Tedika, 2015; Caulderwood, 2015; World Bank, 2015) in spite of (i) over two decades of growth resurgence that began in the mid-1990s (Fosu, 2015) and (ii) the sub-region hosting seven of the ten fastest growing economies in the world (Asongu \& Rangan, 2015). According to the narrative, about 45 percent of countries were off-track from attaining the MDGs poverty target.

Some indicators for measuring inclusive growth have been proposed in recent literature. The most notable to the best of our knowledge is from Anand et al. (2013) and Mlachila et al. (2014). The former which accounts for inequality is drawn from the literature documenting the imperative for inclusive growth to mitigate poverty in a sustainable manner (Kraay, 2004; Berg et al., 2011ab). Conversely, to relative pro-poor growth (Dollar \& Kraay, 2002), these authors adopt the concept of absolute pro-poor growth in line with Ravallion and Chen (2003). The former argues that growth is inclusive on the condition that it reduces inequality with more equalizing income distribution that benefits the poor while the latter considers inclusive growth as growth that benefits the poor in absolute terms. According to Anand et al. (2013), the alternative or relative concept could affect both rich and poor households with unfavourable or sub-optimal externalities. Their definition of inclusiveness and understanding of inclusive growth entail features like: market protection, employment transitions, equity and equal opportunities. In this light, their measurement of inclusive growth encompasses growth that is increasing with economic expansion factoring-in inter alia: productivity, increasing investment and equal employment opportunities.

The latter or Mlachila et al. (2014) have drawn on the former (Anand et al., 2013) as well as a combination of previous definitions, concepts and measurements of pro-poor growth to provide a new measurement called the Quality of Growth Index (QGI). The new index which builds on Ianchovichina and Gable (2012) and the Commission on Growth and Development (2008) is based on a current stream in the literature providing evidence on 'immiserizing growth' that is associated with growing unemployment, poverty and inequality in regions like sub-Saharan Africa (SSA) (Ola-David \& Oyelaran-Oyeyinka, 2014; Dollar et 
al., 2013; Dollar \& Kraay, 2002; Martinez \& Mlachila, 2013). The GQI conceives 'inclusive growth' to be 'pro-poor growth' that is durable, high and socially-friendly. Hence, some important dimensions critical for 'growth quality' include increasing productivity, strength, sustainability, stability, poverty mitigation and better living standards. The present study focuses on extending Mlachila et al. (2014) to integrate social dimensions in the intrinsic measurement of growth.

But before we show how Mlachila et al. (2014) is relevant to the present line of inquiry, it is first of all imperative to (i) provide a linkage between stylized facts on the relationship between Sub-Saharan Africa's extreme poverty tragedy and the QGI and (ii) discuss why social welfare in health and education are reducing the QGI in SSA. Given that growth in the sub-continent has fundamentally been driven by resource-rich countries (Asongu, 2015), we use some case studies of resource-rich countries to substantiate the narrative. We consider the examples of Equatorial Guinea, the Republic of Congo and Gabon used by Ndikumana and Boyce (2012) and compare with corresponding 'quality of growth' performance from Mlachila et al. (2014).

On the first point, the GQI measure by the International Monetary Fund (IMF) shows a significant deterioration in the rankings of the underlying countries during the sampled period (1990-2011) (Mlachila et al., 2014). In essence, based on a comparative examination of 93 developing countries during four non-overlapping periods (1990-1994, 1995-1999, 20002004 and 2005-2011) the countries under consideration have seen their quality of growth consistently deteriorate, notably: (i) $58^{\text {th }}, 61^{\text {st }}, 67^{\text {th }}$ and $69^{\text {th }}$ for Gabon; (ii) $59^{\text {th }}, 70^{\text {th }}, 74^{\text {th }}$ and $84^{\text {th }}$ for the Congo Republic and (iii) $76^{\text {th }}, 73^{\text {rd }}, 76^{\text {th }}$ and $88^{\text {th }}$ for Equatorial Guinea.

With regard to the second point, consistent with Ndikumana and Boyce (2012), whereas Equatorial Guinea, Gabon and the Republic of Congo are in the club of Africa's wealthiest countries with respective overall rankings of $15^{\text {th }}, 2^{\text {nd }}$ and $5^{\text {th }}$ and corresponding per capita incomes of $\$ 1,253, \$ 8,649$ and $\$ 4,176$, they are also among the poorest in terms of educational and health amenities. Moreover, while these nations have been blessed with an abundance of oil reserves, with respective ranks of $10^{\text {th }}, 7^{\text {th }}$ and $8^{\text {th }}$, their citizens are living with lamentable poverty standards ${ }^{1}$. According to the narrative, they lack basic social facilities like drinkable water, elementary schools, good sanitation and health care. For instance, when it comes to the vaccination of the population against measles or immunisation against the disease, Equatorial Guinea and Gabon rank third- and second-to-the last with

\footnotetext{
${ }^{1}$ It is important to note that the GDP per capita measurements from Ndikumana and Boyce (2012) are not updated.
} 
51and 55 percent respectively. The odds of a child celebrating his/her fifth birthday in Equatorial Guinea are higher compared with the average for SSA.

In light of the above characteristics of high-growth countries, the QGI determinants documented by Mlachila et al. (2014) could be improved to incorporate at least two dimensions (i) the Hopeful status in terms of quality of growth performance and (ii) poor social conditions. First, while the underlying study has documented seven fundamental features, we focus on the time-consistent growth quality performance characteristics that are highlighted but not exploited ${ }^{2}$. These are: Hopefuls, Contenders and Best Performers in growth quality. We extrapolate countries corresponding to Hopefuls and discover that almost all members of this category are in SSA. As shown in Table 1, with the exception of Yemen and Pakistan, 31 of the 33 countries from this category are from SSA, which is broadly consistent with the 2015 World Bank publication. Second, given the crucial role of the socially-friendly feature in the composition of the QGI, we decompose the social spending variable into its health and educational components in order to (i) emphasise the welfare dimension articulated in the stylized facts and (ii) provide more room for policy implications.

On the methodological front, instead of examining the determinants of the mean of the dependent variable as in the underling study, we assess the determinants throughout the conditional distributions of the QGI. The intuition for this extension is that determinants could vary across high-QGI and low-QGI countries such that blanket policies are inefficient unless they are contingent on initial levels of QGI and tailored differently across low-QGI and highQGI countries. Quantile Regressions (QR) are used for this purpose. This empirical strategy also enables us to go beyond the superficial sign-reporting of estimated coefficients of determinants of the QGI. Hence, in the interpretation of results, we engage the magnitude of coefficients across identified categories and specifications. The research question addressed is as follows: how does welfare spending affect the quality of growth when existing levels of quality of growth matter?

The rest of the study is organised as follows. Section 2 discusses the data and methodology. The empirical results are presented in Section 3, while Section 4 concludes with implications and future research directions.

\footnotetext{
${ }^{2}$ The features are provided in Figure 4 and Figures 2-3. We shall employ 'underlying study' and Mlachila et al. (2014) interchangeably throughout the study.
} 
Table 1: Categorization of countries

\begin{tabular}{|c|c|c|c|}
\hline Categories & Panels & Countries & Number \\
\hline \multirow{3}{*}{ Performance } & Hopefuls & $\begin{array}{l}\text { "Burundi, Benin, Burkina Faso, Bangladesh, Central African } \\
\text { Republic, Côte d'Ivoire, Cameroon, Congo Republic, Djibouti, } \\
\text { Ethiopia, Gabon, Guinea, The Gambia, Equatorial Guinea, } \\
\text { Lesotho, Madagascar, Mali, Mozambique, Mauritania, Malawi, } \\
\text { Niger, Nigeria, Pakistan, Rwanda, Sudan, Senegal, Sierra } \\
\text { Leone, Swaziland, Chad, Togo, Uganda, Yemen, Congo } \\
\text { Democratic Republic". }\end{array}$ & 33 \\
\hline & Contenders & $\begin{array}{l}\text { "Azerbaijan, Bolivia, Georgia, Ghana, Guatemala, Iran, Lao } \\
\text { PDR, Morocco, Mongolia, Namibia, Nicaragua, Nepal, } \\
\text { Tajikistan, Tanzania, Uzbekistan, Zambia". }\end{array}$ & 16 \\
\hline & Best Performers & $\begin{array}{l}\text { "Albania, Argentina, Armenia, Bulgaria, Belarus, Brazil, } \\
\text { Botswana, Chile, China, Colombia, Costa Rica, Cuba, Algeria, } \\
\text { Ecuador, Egypt, Honduras, Indonesia, India, Jordan, } \\
\text { Kazakhstan, Kenya, Kyrgyz Republic, Sri Lanka, Lithuania, } \\
\text { Latvia, Moldova, Mexico, Malaysia, Panama, Peru, Philippines, } \\
\text { Poland, Paraguay, Romania, Russia, El Salvador, Syria, } \\
\text { Thailand, Tunisia, Turkey, Uruguay, Venezuela, Vietnam, } \\
\text { South Africa". }\end{array}$ & 44 \\
\hline
\end{tabular}

Sources: Mlachila et al. (2014) and the Authors'.

\section{Data and Methodology}

\subsection{Data}

We examine a panel of 93 developing countries with data for the period 1990-2011 from Mlachila et al. (2014). The dataset which is in the public domain consists of four nonoverlapping intervals: 1990-1994; 1995-1999; 2000-2004 and 2005-2011. Therefore the data average is according to the intervals provided by Mlachila et al. (2014). Computation of the QGI is based on data from a plethora of sources, namely: Sala-i-Martin (2006), Barro and Lee (2010), United Nations(UN) COMTRADE database, the IMF's World Economic Outlook and World Development Indicators of the World Bank.

Consistent with the motivation of this study, the dependent variable is the QGI whereas welfare and/or social spending indicators are education and health expenditure. The QGI is a composite (arithmetic mean) indicator of sub-indexes that capture the 'growth nature' aspect and the 'desirable social outcomes' aspect of inclusive development ${ }^{3}$. 'Education spending' is defined as public resources allocated to education as percent of GDP while 'health spending' is defined as public resources allocated to heath as percent of GDP.

\footnotetext{
${ }^{3}$ We invite the interested reader to gain more insights into the construction of the dependent variable in Mlachila et al. (2014) because engaging the construction of the dependent variable would be a repetition of what is already covered by Mlachila et al. (2014).
} 
It should be noted that, contrary to the underlying study, we have decomposed social spending into its health and educational components for the purpose of this study. The control variables defined in Appendix 1 include: government stability, inflation, private domestic credit, foreign direct investment (FDI), remittances, foreign aid, rule of law and quality of bureaucracy. Government stability is an index ranging from 0 to 12 and measuring the ability of government to stay in office and to carry out its declared program(s). The higher the index, the more stable the government. Inflation is based on the Consumer Price Index (CPI). Credit to the private sector is credit offered by banks to the private sector as a percent of GDP.

Foreign direct investment refers to net inflows of foreign direct investments, as percent of GDP. Remittances refer to workers' remittances and compensation of employees (percent of GDP), calculated as the sum of workers' remittances, compensation of employees and migrants' transfers. The rule of law is an index assessing the strength and the impartiality of the legal system, as well as the popular observance of the law. The index ranges from 0 to 6 , with a higher value of the index reflecting a higher institutional quality. Quality of bureaucracy is the Index of the institutional strength and quality of the bureaucracy ranging from 0 to 4 . The higher the index, the stronger the quality of the bureaucracy.

The control variables employed are broadly in line with Anand et al. (2013) in the inclusive growth literature. With the exception of inflation, which we expect to reduce quality of growth when it is high owing to diminishing purchasing power, other control variables are expected, for the most part to display positive signs. In essence, whereas high inflation mitigates growth quality, inflation that is low and stable is positive for income-equalization (Asongu, 2013a) and stimulation of investment to boost economic growth (Asongu, 2013a). This is fundamentally because high inflation creates uncertainty due to growing ambiguity and investors have been documented to prefer less ambiguous economic strategies (Le Roux $\&$ Kelsey, 2016ab). On the positive indicators, they have been substantially documented in the bulk of inclusive growth literature (Dollar \& Kraay, 2003; Barro \& Lee, 2000; Calderon \& Servén, 2004; Levine, 2005; Hausmann et al., 2007; IMF, 2007; Mishra, et al., 2011; Anand et al., 2012; Seneviratne \& Sun, 2013; Asongu \& Nwachukwu, 2016ab).

We devote some space to engaging the highlighted literature in detail. Consistent with the IMF (2007) and Anand et al. (2013), human capital, structural change and macroeconomic stability are relevant pro-growth determinants in developing countries. While structural change entails globalisation (FDI and trade), human capital and macroeconomic stability embody, inter alia: educational levels, technological change and fixed investment. Other structural and macroeconomic features essential for the growth process are inflation and 
output volatility (Dollar \& Kraay, 2003; Barro \& Lee, 2010), finance (Levine, 2005); infrastructural development (Calderon \& Servén, 2004; Seneviratne \& Sun, 2013); development of value chains (Hausmann et al., 2007; Anand, et al., 2012) and production modernization (Mishra et al., 2011). The summary statistics are presented in Appendix 2 whereas the correlation matrix is in Appendix 3. From the summary statistics we observe that (i) the means are comparable and (ii) the variables exhibit a substantial degree of variation, hence we can be confident that reasonable estimated relationships would emerge. It is for the purpose of having comparable variables that some indicators are presented in logarithms.

The purpose of the correlation matrix is to mitigate potential issues of multicollinearity. After a preliminary assessment, it is apparent that covariates do not have a very high degree of substitution.

\subsection{Methodology}

Consistent with the motivation of the study, we adopt Quantile regression (QR). The QR technique consists of assessing the determinants of growth quality throughout the conditional distributions of the dependent variable. That is from low-QGI to high-QGI countries. It yields parameters estimated at various thresholds in the conditional distributions of the QGI (Koenket \& Hallock, 2001). This is in line with the underlying literature on conditional determinants (Billger \& Goel, 2009; Asongu, 2013b) which is focused on investigating if initial levels of the dependent variable matter in the effects of underlying determinants.

Mlachila et al. (2014) reported estimated parameters at the conditional mean of quality of growth. Whereas mean impacts are important, we improve the underlying study by employing the QR estimation strategy to account for initial quality of growth levels. In essence, while Ordinary Least Squares (OLS) for instance may assume that the QGI and error terms are normally distributed, the $\mathrm{QR}$ is not based on this assumption. In essence, with $\mathrm{QR}$, parameter estimates are derived at multiple points of the conditional distributions of quality of growth (Koenker \& Bassett, 1978). The QR estimation strategy is increasingly being employed in development literature, inter alia in: health (Asongu, 2014), corruption (Billger \& Goel, 2009; Okada \& Samreth, 2012) and quality of growth (Asongu \& Rangan, 2015) studies. Therefore, the techinque enables us to examine the effects of social spending (health and education) on quality of growth with particular emphasis on best- and worst-performing developing countries in terms of growth quality. 
The $\theta^{\text {th }}$ quantile estimator of growth quality is obtained by solving for the following optimization problem, which is presented without subscripts in Eq. (1) for the purpose of simplicity and readability.

$$
\min _{\beta \in R^{k}}\left[\sum_{i \in\left\{i: y_{i} \geq x_{i}^{\prime} \beta\right.} \theta\left|y_{i}-x_{i^{\prime}} \beta\right|+\sum_{i \in\left\{i: y_{i} \geq x_{i^{\prime}} \beta\right.}(1-\theta)\left|y_{i}-x_{i^{\prime}} \beta\right|\right]
$$

Where $\theta \in(0,1)$. Contrary to OLS which is fundamentally based on minimizing the sum of squared residuals, with QR, the weighted sum of absolute deviations are minimised. For example the $10^{\text {th }}$ or $25^{\text {th }}$ quantiles (with $\theta=0.10$ or 0.25 respectively) by approximately weighing the residuals. The conditional quantile of growth quality or $y_{i}$ given $x_{i}$ is:

$$
Q_{y}\left(\theta / x_{i}\right)=x_{i} \beta_{\theta}
$$

Where unique slope parameters are modelled for each $\theta^{\text {th }}$ specific quantile. This formulation is analogous to $E(y / x)=x^{\prime} \beta$ in the OLS slope where parameters are assessed only at the mean of the conditional distribution of 'quality of growth'. For Eq. (2) the dependent variable $y_{i}$ is the quality of growth indicator while $x_{i}$ contains: a constant term, health spending, educational spending, government stability, inflation, credit, FDI, remittances, foreign aid, rule of law and quality of bureaucracy. The empirical evidence is based on data with five year averages, for the most part.

While the growth categories are provided by Mlachila et al. (2014), our estimation approach also enables us to classify the sample into three categories based on quantiles. With Quantile Regressions, low quantiles indicate countries with low values in the dependent variable while higher quantiles indicate countries with higher values in the dependent variable. Therefore, by dividing the sample into nine quantiles, the three distinctions in Mlachila et al. (2014) can be emphasised by our estimation technique.

\section{Empirical results}

The empirical results are presented in Table 2. Increasing the conditioning information set is a form of testing if baseline regressions withstand further empirical scrutiny when more factors are accounted for. Two control variables are used in the first specification, before more are used in the second specification. This discussion is provided here in Section 3.

Conditional distributions are divided into three main categories to articulate Hopefuls $(0.10$, $0.20 \& 0.30)$, Contenders $(0.40,0.50 \& 0.60)$, and Best performers $(0.70,0.80 \& 0.90)$ in 
terms of growth quality. Two main specifications are provided: the first with a limited conditioning information set (or control variables) and the second with more control variables to assess robustness of baseline estimations.

The following findings can be established from the first specification. First, health spending has a positive threshold effect with decreasing magnitude across the whole distribution from the $0.10^{\text {th }}$ to the $0.80^{\text {th }}$ quantile. Second, as for the impact of educational spending, there is a positive threshold effect with increasing magnitude in each quality of growth category. In other words, there is a positive increasing magnitude from: (i) $0.10^{\text {th }}$ to the $0.30^{\text {th }}$ quantile (Hopefuls); $0.40^{\text {th }}$ to the $0.60^{\text {th }}$ quantile (Contenders) and $0.70^{\text {th }}$ to the $0.90^{\text {th }}$ quantile (Best Performers). Overall, when averages of the categories are compared, the effect of education has a positive threshold effect with increasing magnitude from Hopefuls to Contenders. It is important to note that the assumption of quantitative significance between Hopefuls and Contenders rests on the estimation technique that distinguishes countries in terms of initial levels in quality of growth. The positive effects from education and health spending are consistent with the positive effect of social spending in Mlachila et al. (2014). It is important to also note that we have decomposed social spending into its health and education components. Third, on the control variables, while inflation has the expected sign, government quality has the expected effect only in the $0.10^{\text {th }}$ quantile. However, the magnitude of the latter control variable is low.

In the second specification, the following can be established. First, health spending has a positive threshold effect with decreasing magnitude across the whole distribution from the $0.10^{\text {th }}$ to the $0.60^{\text {th }}$ quantile. Conversely, there is a threshold positive effect with increasing magnitude among Best Performers $\left(0.10^{\text {th }}\right.$ to the $0.90^{\text {th }}$ quantile). Second, on education spending: while there is a positive effect with inverted U-shaped tendency among Hopefuls and Contenders, the corresponding positive effect is U-shaped among Best Performers. Overall, when averages of categories are compared, education has a positive threshold effect with increasing magnitude from Hopefuls to Contenders. Third, most of the significant control variables have the expected signs. While government quality, private credit and quality of bureaucracy have positive effects, the impact of remittances is negative. The positive effects of government quality and private credit are consistent with Mlachila et al. (2014). 
Table 2: Conditional effects of health and education spending

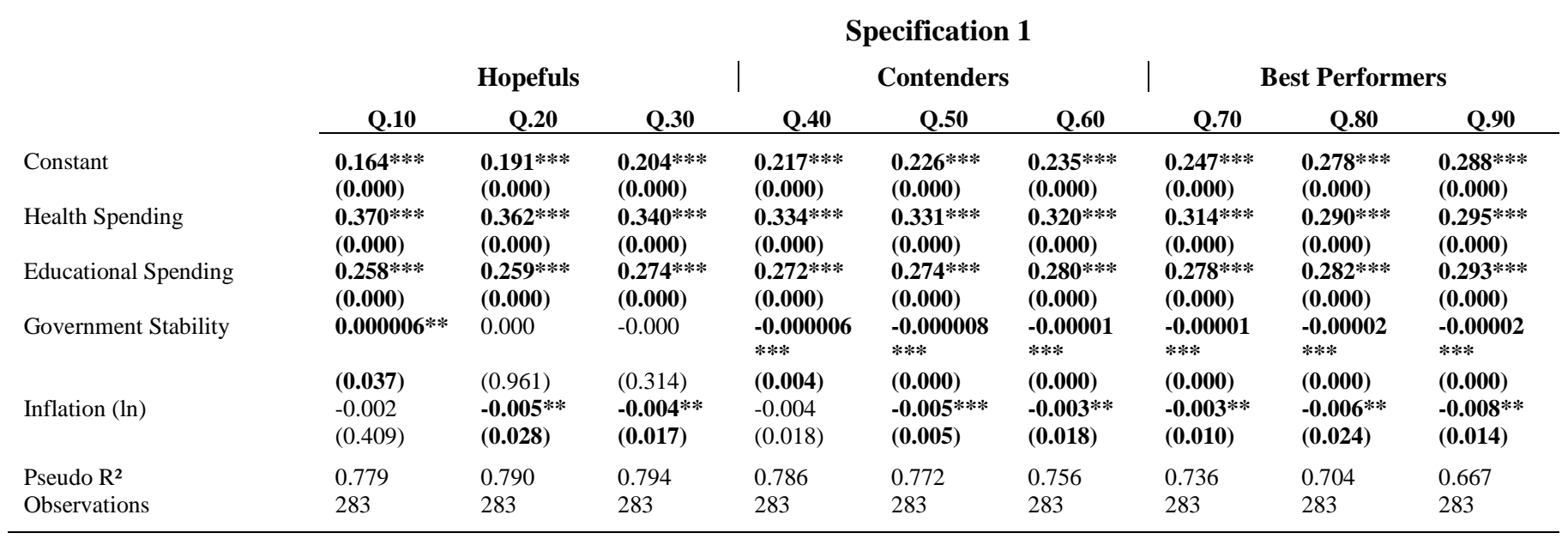

\begin{tabular}{|c|c|c|c|c|c|c|c|c|c|}
\hline & \multicolumn{3}{|c|}{ Hopefuls } & \multicolumn{3}{|c|}{ Contenders } & \multicolumn{3}{|c|}{ Best Performers } \\
\hline & Q.10 & Q.20 & Q.30 & Q.40 & Q.50 & Q.60 & Q.70 & Q.80 & Q.90 \\
\hline Constant & $\begin{array}{l}\text { 0.109** } \\
(0.011)\end{array}$ & $\begin{array}{l}\text { 0.121*** } \\
(0.001)\end{array}$ & $\begin{array}{l}0.117 \\
(0.000)\end{array}$ & $\begin{array}{l}\mathbf{0 . 1 4 8 * * *} \\
(0.000)\end{array}$ & $\begin{array}{l}\mathbf{0 . 1 5 7} * * * \\
(\mathbf{0 . 0 0 0 )}\end{array}$ & $\begin{array}{l}\mathbf{0 . 1 8 5 * * *} \\
(\mathbf{0 . 0 0 0 )}\end{array}$ & $\begin{array}{l}0.210 * * * * \\
(0.000)\end{array}$ & $\begin{array}{l}0.218 * * * \\
(0.000)\end{array}$ & $\begin{array}{l}\text { 0.199**** } \\
(\mathbf{0 . 0 0 0 )}\end{array}$ \\
\hline Health Spending & $\begin{array}{l}0.375 * * * \\
(0.000)\end{array}$ & $\begin{array}{l}0.347 * * * \\
(\mathbf{0 . 0 0 0 )}\end{array}$ & $\begin{array}{l}0.334 * * * \\
(\mathbf{0 . 0 0 0 )}\end{array}$ & $\begin{array}{l}0.318 * * * \\
(0.000)\end{array}$ & $\begin{array}{l}0.302 * * * \\
(0.000)\end{array}$ & $\begin{array}{l}0.288 * * * \\
(0.000)\end{array}$ & $\begin{array}{l}0.298 * * * \\
(0.000)\end{array}$ & $\begin{array}{l}0.301 * * * \\
(0.000)\end{array}$ & $\begin{array}{l}0.319 * * * \\
(0.000)\end{array}$ \\
\hline Educational Spending & $\begin{array}{l}0.245 * * * \\
(0.000)\end{array}$ & $\begin{array}{l}0.254 * * * \\
(0.000)\end{array}$ & $\begin{array}{l}0.244 * * * \\
(0.000)\end{array}$ & $\begin{array}{l}0.252 * * * \\
(\mathbf{0 . 0 0 0 )}\end{array}$ & $\begin{array}{l}0.267 * * * \\
(0.000)\end{array}$ & $\begin{array}{l}0.266 * * * \\
(0.000)\end{array}$ & $\begin{array}{l}\text { 0.278**** } \\
(0.000)\end{array}$ & $\begin{array}{l}0.274 * * * \\
(0.000)\end{array}$ & $\begin{array}{l}0.285 * * * \\
(0.000)\end{array}$ \\
\hline Government Stability & $\begin{array}{l}0.002 \\
(0.421)\end{array}$ & $\begin{array}{l}0.002 \\
(0.314)\end{array}$ & $\begin{array}{l}0.004 * * \\
(0.034)\end{array}$ & $\begin{array}{l}\mathbf{0 . 0 0 4} * * * \\
(\mathbf{0 . 0 0 3 )}\end{array}$ & $\begin{array}{l}\mathbf{0 . 0 0 4} * * * \\
(0.003)\end{array}$ & $\begin{array}{l}0.004 * * \\
(0.026)\end{array}$ & $\begin{array}{l}0.003 \\
(0.328)\end{array}$ & $\begin{array}{l}0.004 \\
(0.232)\end{array}$ & $\begin{array}{l}0.003 \\
(0.374)\end{array}$ \\
\hline Inflation (ln) & $\begin{array}{l}0.002 \\
(0.738)\end{array}$ & $\begin{array}{l}0.0005 \\
(0.908)\end{array}$ & $\begin{array}{l}0.005 \\
(0.135)\end{array}$ & $\begin{array}{l}0.004 \\
(0.105)\end{array}$ & $\begin{array}{l}0.003 \\
(0.204)\end{array}$ & $\begin{array}{l}0.003 \\
(0.230)\end{array}$ & $\begin{array}{l}0.003 \\
(0.495)\end{array}$ & $\begin{array}{l}0.002 \\
(0.627)\end{array}$ & $\begin{array}{l}0.006 \\
(0.216)\end{array}$ \\
\hline Credit (ln) & $\begin{array}{l}\text { 0.009* } \\
(0.065)\end{array}$ & $\begin{array}{l}0.015 * * \\
(0.011)\end{array}$ & $\begin{array}{l}\text { 0.018*** } \\
(0.006)\end{array}$ & $\begin{array}{l}\mathbf{0 . 0 1 3} * * * \\
(\mathbf{0 . 0 0 3 )}\end{array}$ & $\begin{array}{l}0.013 * * * \\
(0.004)\end{array}$ & $\begin{array}{l}0.006 \\
(0.204)\end{array}$ & $\begin{array}{l}0.0006 \\
(0.941)\end{array}$ & $\begin{array}{l}-0.001 \\
(0.878)\end{array}$ & $\begin{array}{l}0.002 \\
(0.837)\end{array}$ \\
\hline Foreign Direct Investment & $\begin{array}{l}-0.001 \\
(0.501)\end{array}$ & $\begin{array}{l}-0.0001 \\
(0.943)\end{array}$ & $\begin{array}{l}0.00001 \\
(0.991)\end{array}$ & $\begin{array}{l}0.00006 \\
(0.947)\end{array}$ & $\begin{array}{l}-0.0003 \\
(0.752)\end{array}$ & $\begin{array}{l}-0.0006 \\
(0.575)\end{array}$ & $\begin{array}{l}0.0002 \\
(0.888)\end{array}$ & $\begin{array}{l}0.0001 \\
(0.928)\end{array}$ & $\begin{array}{l}-0.0009 \\
(0.716)\end{array}$ \\
\hline Remittances & $\begin{array}{l}-0.0009 \\
(0.532)\end{array}$ & $\begin{array}{l}-0.0008 \\
(0.448)\end{array}$ & $\begin{array}{l}-0.001 \\
(0.233)\end{array}$ & $\begin{array}{l}-\mathbf{- 0 . 0 0 1 *} \\
(0.097)\end{array}$ & $\begin{array}{l}-\mathbf{- 0 . 0 0 1 *} \\
(0.060)\end{array}$ & $\begin{array}{l}-0.0006 \\
(0.389)\end{array}$ & $\begin{array}{l}-0.001 \\
(0.163)\end{array}$ & $\begin{array}{l}-\mathbf{0 . 0 0 2} * * \\
(0.021)\end{array}$ & $\begin{array}{l}-0.003 * * \\
(0.016)\end{array}$ \\
\hline Foreign Aid & $\begin{array}{l}0.0006 \\
(0.471)\end{array}$ & $\begin{array}{l}0.0002 \\
(0.821)\end{array}$ & $\begin{array}{l}0.0002 \\
(0.767)\end{array}$ & $\begin{array}{l}-0.0002 \\
(0.727)\end{array}$ & $\begin{array}{l}-0.0002 \\
(0.662)\end{array}$ & $\begin{array}{l}-0.0004 \\
(0.548)\end{array}$ & $\begin{array}{l}-0.0008 \\
(0.553)\end{array}$ & $\begin{array}{l}-0.0002 \\
(0.874)\end{array}$ & $\begin{array}{l}-0.0001 \\
(0.898)\end{array}$ \\
\hline Rule of Law & $\begin{array}{l}0.004 \\
(0.234)\end{array}$ & $\begin{array}{l}0.001 \\
(0.707)\end{array}$ & $\begin{array}{l}-0.002 \\
(0.514)\end{array}$ & $\begin{array}{l}-0.002 \\
(0.428)\end{array}$ & $\begin{array}{l}-0.001 \\
(0.576)\end{array}$ & $\begin{array}{l}0.0006 \\
(0.817)\end{array}$ & $\begin{array}{l}0.0001 \\
(0.978)\end{array}$ & $\begin{array}{l}0.002 \\
(0.555)\end{array}$ & $\begin{array}{l}0.004 \\
(0.485)\end{array}$ \\
\hline Bureaucracy & $\begin{array}{l}0.002 \\
(0.746)\end{array}$ & $\begin{array}{l}0.0003 \\
(0.957)\end{array}$ & $\begin{array}{l}0.001 \\
(0.745)\end{array}$ & $\begin{array}{l}0.003 \\
(0.329)\end{array}$ & $\begin{array}{l}0.004 \\
(0.306)\end{array}$ & $\begin{array}{l}0.007 * \\
(0.084)\end{array}$ & $\begin{array}{l}0.006 \\
(0.404)\end{array}$ & $\begin{array}{l}0.006 \\
(0.449)\end{array}$ & $\begin{array}{l}0.002 \\
(0.732)\end{array}$ \\
\hline Pseudo $\mathrm{R}^{2}$ & 0.846 & 0.833 & 0.831 & 0.830 & 0.824 & 0.812 & 0.796 & 0.777 & 0.755 \\
\hline Observations & 147 & 147 & 147 & 147 & 147 & 147 & 147 & 147 & 147 \\
\hline
\end{tabular}

$* * * ; * * *:$ significance levels of 1\%,5\% and 10\% respectively. Lower quantiles (e.g., Q 0.1) signify nations where Growth is least. Ln: logarithm.

\section{Concluding implications and future research directions}

We have observed from the above that, but for some slight exceptions in the findings of Specification 2, the results of Specification 1 are broadly consistent with those of Specification 2. The exceptions include: (i) the Best Performers category for health spending and (ii) shapes of all categories in the positive effects of education spending. In a situation of conflict of interest, while it would be logical to give preference to the findings of Specification 2 because it entails more control variables, in average terms, the findings of both specifications are consistent, notably the effect of health is decreasingly positive from 
Hopeful, Contenders to Best Performers while the impact of education is increasingly positive in the same chronology of categories. Such differences in effects may be traceable to the fact that education is comparatively more rewarding for quality of growth in high quality of growth countries, while health spending leads to comparatively higher returns in quality of growth in low quality of growth countries. Any attempts at explaining why such differences occur may only be speculative. Such elucidation could be an interesting area of future research.

It should be noted that almost all countries in the Hopeful category are from SSA (with the exceptions of Yemen and Pakistan). It follows that it would benefit countries in the sub-region to invest more in health relative to education now, but decrease health spending and increase education spending respectively relative to education spending and health spending as the economies in the sub-region make the transition from Hopeful to Contenders and finally to Best Performers in terms of 'quality of growth'. In other words, the health elasticity of 'growth quality' is a decreasing function of 'quality of growth' whereas education elasticity of 'growth quality' is an increasing function of 'quality of growth'.

Overall, we have shown that blanket welfare policies on social spending aimed at boosting 'quality of quality' may not be effective unless they are contingent on performance in growth quality and hence tailored differently across Hopefuls, Contenders and Best Performers. This implies policies meant to improve growth quality across in SSA should be different from those of more advanced developing countries in growth quality. Moreover, the findings also have implications for medium- and long-term planning when it comes to the social spending needed to increase the much needed 'quality of growth'. This planning dimension is relevant for the post-2015 Sustainable Development agenda.

Accordingly, this study has been motivated by the transition from the Millennium Development Goals (MDGs) to Sustainable Development Goals (SDGs) that has substantially shifted the policy debate from growth to 'quality of growth' (QG). The April 2015 World Bank publication on MDGs extreme poverty targets has revealed that poverty has been decreasing in all regions of the world with the exception of Sub-Saharan Africa (SSA). We have explored a new dataset on QG by the IMF and classified 93 developing countries for the period 1990-2011 in terms of Hopefuls, Contenders and Best Performers. Preliminary findings reveal that 31 of the 33 countries in the Hopefuls category are in SSA.

We have built on stylized facts depicting the contradiction between high-growth and poor welfare spending and assessed determinants of education and health spending on the QG using quantile regressions to articulate least and best performers. It is important to note that 
'welfare spending' does not include only health and education but that it also includes pensions and other social transfers. Hence, there is a specific part of social spending that is not included in the analysis. The following findings have been established. First, on average, the effect of health (education) is decreasingly (increasingly) positive from Hopeful to Best Performers. Second, within categories (1) health spending has positive threshold effects with decreasing magnitude among Hopefuls $\left(0.10^{\text {th }}\right.$ to $0.30^{\text {th }}$ quantiles $)$ and Contenders $\left(0.40^{\text {th }}\right.$ to $0.60^{\text {th }}$ quantile), and the positive effects with increasing magnitude among Best Performers $\left(0.10^{\text {th }}\right.$ to $0.90^{\text {th }}$ quantile $)$ and (2) education spending has a positive inverted U-shaped effects among Hopefuls and Contenders and positive U-shaped effects among Best Performers..

Policy implications have been discussed. The study which partially elucidates SSA's extreme poverty tragedy is timely and relevant for the post-2015 inclusive and sustainable development agenda. There is evidently room for further research on (i) comparative countryspecific case studies and (ii) other welfare variables, for more focused policy implications. Further research can also use interactive regressions to assess whether low social spending is beneficial to low performing countries while high social spending is beneficial to high performing countries. This recommendation is consistent with a discovery by Harding and Lamarche (2014) that smaller classes are beneficial for low performers and larger classes are beneficial for high performers. 
Appendices

Appendix 1: Definition of variables

\begin{tabular}{|c|c|c|}
\hline Variable(s) & Definition(s) & Source(s) \\
\hline $\begin{array}{l}\text { Quality of Growth } \\
\text { Index (QGI) }\end{array}$ & $\begin{array}{l}\text { "Composite index ranging between } 0 \text { and } 1 \text {, resulting from the } \\
\text { aggregation of components capturing growth fundamentals and from } \\
\text { components capturing the socially-friendly nature of growth. The } \\
\text { higher the index, the greater is the quality of growth" (p. 25). }\end{array}$ & $\begin{array}{l}\text { Mlachila et al. } \\
\qquad(2014)\end{array}$ \\
\hline $\begin{array}{l}\text { Educational } \\
\text { Spending }\end{array}$ & $\begin{array}{l}\text { "Public resources allocated to education spending, as percent of GDP" } \\
\text { (p. 25) }\end{array}$ & IMF dataset \\
\hline Health Spending & $\begin{array}{l}\text { "Public resources allocated to heath spending, as percent of GDP" (p. } \\
25)\end{array}$ & IMF dataset \\
\hline $\begin{array}{l}\text { Government } \\
\text { Stability }\end{array}$ & $\begin{array}{l}\text { "Index ranging from } 0 \text { to } 12 \text { and measuring the ability of government } \\
\text { to stay in office and to carry out its declared program(s).The higher } \\
\text { the index, the more stable the government is" ( } \mathrm{p} .25) \text {. }\end{array}$ & $\begin{array}{l}\text { International } \\
\text { Country Risk } \\
\text { Guide (ICRG, } \\
\text { 2009) }\end{array}$ \\
\hline Inflation & Inflation rate based on the Consumer Price Index (CPI) & $\begin{array}{l}\text { World } \\
\text { Economic } \\
\text { Outlook }\end{array}$ \\
\hline $\begin{array}{l}\text { Credit to private } \\
\text { sector }\end{array}$ & $\begin{array}{l}\text { "Domestic credit to private sector, namely credit offered by the banks } \\
\text { to the private sector, as percent of GDP" (p. 25). }\end{array}$ & World \\
\hline $\begin{array}{l}\text { Foreign Direct } \\
\text { Investment }\end{array}$ & “Net Inflows of Foreign Direct Investments, as percent of GDP" (p. 25) & $\begin{array}{l}\text { Development } \\
\text { Indicators }\end{array}$ \\
\hline Remittances & $\begin{array}{l}\text { "Workers' remittances and compensation of employees (Percent of } \\
\text { GDP), calculated as the sum of workers' remittances, compensation of } \\
\text { employees and migrants' transfers" (p. 25). }\end{array}$ & \\
\hline Foreign Aid & $\begin{array}{l}\text { "Official development Aid actually disbursed, as percent of GDP” (p. } \\
\text { 25) }\end{array}$ & $\begin{array}{l}\text { Guillaumont } \\
\text { and Tapsoba } \\
\text { (2012) }\end{array}$ \\
\hline Rule of Law & $\begin{array}{l}\text { "Index assessing the strength and the impartiality of the legal system, } \\
\text { as well as the popular observance of the law. The index ranges from } 0 \\
\text { to 6, with a higher value of the index reflecting a higher institutional } \\
\text { Quality" (p. 25). }\end{array}$ & $\begin{array}{l}\text { International } \\
\text { Country Risk } \\
\text { Guide (ICRG, }\end{array}$ \\
\hline $\begin{array}{l}\text { Quality of } \\
\text { Bureaucracy }\end{array}$ & $\begin{array}{l}\text { "Index of the institutional strength and quality of the bureaucracy, } \\
\text { ranging from } 0 \text { to } 4 \text {. The higher the index, the stronger the quality of } \\
\text { the bureaucracy" (p. 25) }\end{array}$ & 2009) \\
\hline
\end{tabular}

\section{Appendix 2: Summary Statistics}

\begin{tabular}{lccccc}
\hline & Mean & S. D & Minimum & Maximum & Obs \\
\cline { 2 - 5 } Quality of Growth Index (QGI) & 0.604 & 0.140 & 0.258 & 0.849 & 372 \\
Educational Spending & 0.612 & 0.263 & 0.000 & 1.000 & 372 \\
Health Spending & 0.676 & 0.208 & 0.089 & 0.995 & 372 \\
Government Stability & 18.518 & 165.55 & 2.666 & 2873.8 & 303 \\
Inflation (log) & 2.331 & 1.358 & -0.637 & 8.767 & 339 \\
Domestic Credit (log) & 3.355 & 0.798 & 0.529 & 5.131 & 345 \\
Foreign Direct Investment & 3.225 & 4.867 & -4.172 & 62.264 & 366 \\
Remittances & 4.117 & 7.391 & 0.001 & 63.295 & 322 \\
Foreign Aid & 4.921 & 5.771 & -9.546 & 36.317 & 226 \\
Rule of Law & 3.290 & 1.060 & 0.666 & 5.933 & 301 \\
Quality of Bureaucracy & 1.693 & 0.772 & 0.000 & 4.000 & 301 \\
\hline
\end{tabular}

S.D: Standard Deviation. Obs: Observations. 


\section{Appendix 3: Correlation Matrix}

\begin{tabular}{|c|c|c|c|c|c|c|c|c|c|c|c|}
\hline Educ & Health & GovStab & Infl(log) & Credit(log) & FDI & Remit & Aid & Law & Bureau & QGI & \\
\hline \multirow[t]{11}{*}{1.000} & 0.594 & 0.024 & -0.007 & 0.152 & 0.048 & 0.419 & -0.014 & 0.219 & 0.214 & 0.098 & Educ \\
\hline & 1.000 & 0.036 & 0.032 & 0.231 & 0.133 & 0.265 & -0.070 & 0.214 & 0.228 & 0.340 & Health \\
\hline & & 1.000 & -0.002 & -0.007 & -0.050 & -0.046 & 0.160 & 0.355 & 0.025 & -0.119 & GovStab \\
\hline & & & 1.000 & -0.103 & -0.111 & -0.058 & 0.088 & -0.100 & -0.071 & -0.003 & Infl(log) \\
\hline & & & & 1.000 & -0.047 & -0.018 & -0.230 & 0.235 & 0.464 & 0.551 & Credit(log) \\
\hline & & & & & 1.000 & 0.134 & -0.062 & 0.130 & -0.069 & 0.038 & FDI \\
\hline & & & & & & 1.000 & -0.027 & -0.040 & -0.058 & -0.033 & Remit \\
\hline & & & & & & & 1.000 & -0.059 & -0.304 & -0.572 & Aid \\
\hline & & & & & & & & 1.000 & 0.256 & 0.352 & Law \\
\hline & & & & & & & & & 1.000 & 0.493 & Bureau \\
\hline & & & & & & & & & & & QGI \\
\hline
\end{tabular}

Educ: Educational Spending. Health: Health Spending. GovStab: Government Stability. Infl: Inflation. Credit: Domestic Credit. FDI:

Foreign Direct Investment. Remit: Remittances. Aid: Foreign Aid. Law: Rule of Law. Bureau: Bureaucracy. QGI: Quality of Growth Index.

\section{References}

Anand, R., Mishra, S., \& Peiris, S. J., (2013). "Inclusive Growth: Measurement and Determinants”, IMF Working Paper No. 13/135, Washington.

Anand, R., Mishra, S., \& Spatafora, N., (2012), "Structural Transformation and the Sophistication of Production," IMF Working Paper No. 12/59, Washington.

Asongu, S. A., (2013a). "Investment and Inequality in Africa: Which Financial Channels Are Good for the Poor", African Finance Journal, 15(2), pp. 43-65.

Asongu, S. A., (2013b). "Fighting corruption in Africa: do existing corruption-control levels matter?", International Journal of Development Issues, 12(1), pp. 36-52.

Asongu, S. A., (2014). "The impact of health worker migration on development dynamics: evidence of wealth effects from Africa", The European Journal of Health Economics, 15(2), pp. 187-201.

Asongu, S. A., (2015). "Rational Asymmetric Development, Piketty and the Spirit of Poverty in Africa", African Governance and Development Institute Working Paper No. 15/006, Yaoundé.

Asongu, S. A., \& Kodila-Tedika, O., (2015). "Is Poverty in the African DNA (Gene)?", African Governance and Development Institute Working Paper No. 15/011, Yaoundé.

Asongu, S. A., \& Nwachukwu, J. C., (2016a). "Mobile phones in the diffusion of knowledge and persistence in inclusive human development in Sub-Saharan Africa", Information Development, DOI: 10.1177/0266666916655189.

Asongu, S. A., \& Nwachukwu, J. C., (2016b). "The role of governance in mobile phones for inclusive human development in Sub-Saharan Africa", Technovation, 55-56(SeptemberOctober), pp. 1-13.

Asongu, S. A., \& Rangan, G., (2015). "Trust and Quality of Growth", African Governance and Development Institute Working Paper No. 15/026, Yaoundé. 
Barro, R., \& Lee, J., (2010), “A New Data Set of Educational Attainment in the World, 19502010”, NBER Working Paper No. 15902 (Cambridge, Massachusetts: National Bureau of Economic Research).

Berg, A., \& Ostry, J. D., (2011a), "Inequality and Unsustainable Growth: Two Sides of the Same Coin?" IMF Staff Discussion Note 11/08 (Washington: International Monetary Fund).

Berg, A., \& Ostry, J. D., (2011b), "Equality and Efficiency," Finance \& Development, International Monetary Fund, September 2011, 48(3), pp. 12-15.

Billger, S. M., \& Goel, R. K., (2009), "Do existing corruption levels matter in controlling corruption? Cross-country quantile regression estimates", Journal of Development Economics, 90(2), pp. 299-305.

Boyce J. K., \& Ndikumana L. (2012b), 'Rich Presidents of Poor Nations: Capital Flight from Resource-Rich Countries in Africa', Political Economy Research Institute, University of Massachusetts. http://concernedafricascholars.org/wp-content/uploads/2012/11/caploss01ndiku-14th.pdf (Accessed: 22/06/2015).

Calderon C., \& Servén, L., (2004), "The Effects of Infrastructure Development on Growth and Income Distribution," World Bank Policy Research Working Paper No. 3400, Yaoundé.

Caulderwood, K., (2015) "Sub-Saharan Africa Falls Behind In Fight Against Extreme Poverty: World Bank Report”, International Business Times (April 14th 2015). http://www.ibtimes.com/sub-saharan-africa-falls-behind-fight-against-extreme-povertyworld-bank-report-1881460 (Accessed: 19/04/2015).

Commission on Growth and Development (2008), Growth Report: Strategies for Sustained Growth and Inclusive Development (Washington: World Bank).

Dollar, D., Kleineberg, T., \& Kraay, A., (2013), "Growth is Still Good for the Poor," World Bank Policy Research Working Paper No. 6568 (Washington: World Bank).

Dollar, D., Kleineberg, T., \& Kraay, A., (2002),, "Growth is Good for the Poor," Journal of Economic Growth, 7(3), pp. 195-225.

Dollar, D., \& Kraay, A., (2003), "Institutions, Trade, and Growth," Journal of Monetary Economics, 50, (1), pp. 133-162.

Guillaumont J. S., \& Tapsoba, S. J-A., (2012). “Aid and Income Stabilization”, Review of Development Economics, 16( 2), pp. 216-229.

Harding, M., \& Lamarche, C., (2014). "Estimating and testing a quantile regression model with interactive effects", Journal of Econometrics, 178(1), pp. 101-113.

Hausmann, R., Hwang , J., \& Rodrik, D., (2007), “What You Export Matters,” Journal of Economic Growth, 12(1), pp. 1-25. 
Ianchovichina, E., \& Gable, S. L., (2012), “What is Inclusive Growth?” in Commodity Prices and Inclusive Growth in Low-Income Countries, ed. by Rabah Arezki, Catherine Pattillo, Marc Quintyn, and Min Zhu, International Monetary Fund.

IMF (2007), "Globalization and Inequality," World Economic Outlook, Chapter 4, October, Washington DC.

Koenker, R., \& Bassett, Jr. G. (1978), “Regression quantiles”, Econometrica, 46(1), pp. 3350 .

Koenker, R., \& Hallock, F. K. (2001), “Quantile regression”, Journal of Economic Perspectives, 15(4),pp. 143-156.

Kraay, A., (2004), "When is Growth Pro-Poor? Cross-Country Evidence," IMF Working Paper No. 04/47, Washington.

Krusell, P., \& Smith, T., (2014). “Is Piketty's 'Second Law of Capitalism' Fundamental?”, Institute for International Economic Studies, CEPR and NBER, http://www.iepecdg.com.br/uploads/artigos/piketty1.pdf (Accessed: 02/09/2014).

Levine, R., (2005). "Finance and Growth: Theory and Evidence," Philippe Aghion \& Steven Durlauf (eds.), Handbook of Economic Growth, Edition 1, Volume 1, chapter 12, pp. 865-934.

Lewis, A., (1955). Theory of Economic Growth. Milton Park: Routledge.

Kelsey D \& S le Roux (2016a), "Dragon Slaying with Ambiguity: Theory and Experiments", Journal of Public Economic Theory. doi: 10.1111/jpet.12185

Le Roux, S., \& Kelsey, D., (2016b). "Strategic Ambiguity and Decision-making An Experimental Study”, Department of Economics, Oxford Brookes University.

Martinez, M., \& Mlachila, M., (2013), "The Quality of the Recent High-Growth Episode in Sub-Saharan Africa,” IMF Working Paper 13/53 (Washington: International Monetary Fund).

Mishra, S., Gable, S. L., \& Anand, R., (2011), "Service Export Sophsitication and Economic Growth,” World Bank Policy Working Paper No. 5606, Washington.

Mlachila, M., Tapsoba, R., \& Tapsoba, S. J. A., (2014). “A Quality of Growth Index for Developing Countries: A Proposal”, IMF Working Paper No. 14/172, Washington.

Ola-David, O., \& Oyelaran-Oyeyinka, O., (2014). "Smart Economics: Inclusive Growth, Poverty Alleviation and Decent Employment in Nigeria", SSRN Working Paper http://papers.ssrn.com/sol3/papers.cfm?abstract_id=2505264 (Accessed: 30/12/2014).

Okada, K., \& Samreth, S.,(2012), "The effect of foreign aid on corruption: A quantile regression approach", Economic Letters, 115(2), pp. 240-243.

Piketty, T., (2014). "Capital in the Twenty First Century”, Harvard University Press. 
Ravallion, M., \& Chen, S., (2003), "Measuring Pro-Poor Growth," Economics Letters, 78(1), pp. 93-99.

Reynolds, A., (2014). "Why Piketty's Wealth Data Are Worthless", CATO INSTITUTE, http://www.cato.org/publications/commentary/why-pikettys-wealth-data-areworthless?utm_source=dlvr.it\&utm_medium $=$ twitter\&utm_campaign=Feed $\% 3 \mathrm{~A}+$ CatoRecent Opeds+(Cato+Recent+Op-eds) (Accessed: 02/09/2014).

Sala-i-Martin, X., (2006), "The World Distribution of Income: Falling Poverty and Convergence Period", The Quarterly Journal of Economics, MIT Press, 121(2), pp. 351-97.

Seneviratne, D., \& Sun, Y., (2013), "Infrastructure and Income Distribution in ASEAN-5: What are the Links?" IMF Working Paper No. 13/41, Washington.

World Bank (2015). “World Development Indicators', World Bank Publications http://www.gopa.de/fr/news/world-bank-release-world-development-indicators-2015 (Accessed: 25/04/2015). 